ISSN: $2442-2622$

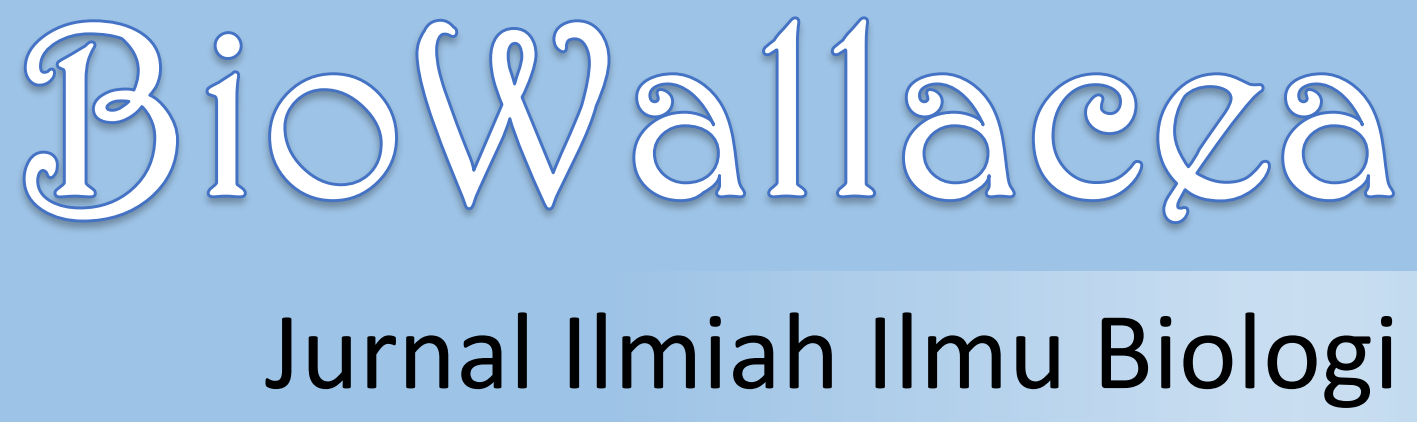

Vol. 3 No. 3 September 2017

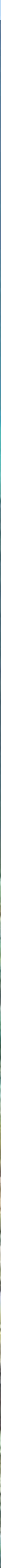




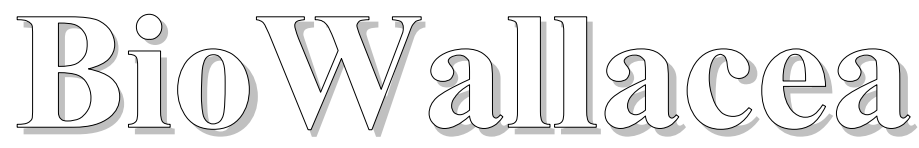

Jurnal Ilmiah Ilmu Biologi

Vol. 1 No. 1 Januari 2015

\author{
Ketua Dewan Editor \\ Faturrahman ( 2017)
}

Editor Pelaksana

Immy Suci Rohyani ( 2017)

\section{Dewan Editor}

I Made Sudarma ( 2017), Surya Hadi ( 2017), Islamul Hadi ( 2017), I Wayan Suana ( 2017), Galuh Tresnani ( 2017), Aida Muspiah ( 2017), Suripto ( 2017), Evy Aryanti ( 2017), Hilman Ahyadi ( 2017), Mursal Ghazali ( 2017), Sukiman ( 2017), dan Sri Puji Astuti ( 2017)

\section{Teknik Editor}

Muhsinul Ihsan ( 2017), Lalu Achmad Tantilar WSK. ( 2017), Supriadi ( 2017), dan Novita Hidayatun Nufus ( 2017)

\section{Menejer Bisnis}

Rina Kurnianingsih ( 2017)

\section{Penerbit}

Program Studi Biologi, Fakultas Matematika dan Ilmu Pengetahuan Alam, Universitas Mataram

\section{Alamat Redaksi}

Program Studi Biologi, Fakultas MIPA, Universitas Mataram, Jalan Majapahit No. 62 Mataram; Telp/Fax : 0370-646506; Email : biologi.fmipa@unram.ac.id; Twitter : biologifmipaunram; $\mathrm{Fb}$ : biologifmipa universitas mataram 


\section{DAFTAR ISI}

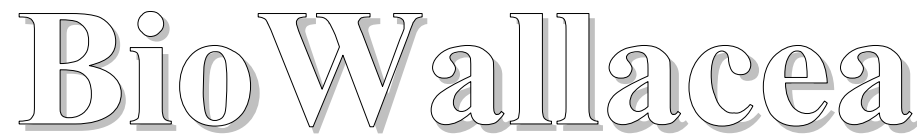

Jurnal Ilmiah Ilmu Biologi

Vol. 3 No. 3 September 2017

Artikel

PENGARUH KONSENTRASI EKSTRAK DAUN PEPAYA

DAN MADU TRIGONA TERHADAP PERTUMBUHAN

BAKTERI PENYEBAB JERAWAT Staphylococcus aureus

MENGUBAH URIN SAPI MENJADI PUPUK ORGANIK

CAIR BERMUTU

HISTOLOGI PANKREAS TIKUS DIABETES SETELAH PEMBERIAN SUSPENSI BIJI BUAH MAKASAR (Brucea

javanica (L.) Merr)

PENYAKIT PADA RUMPUT LAUT HASIL BUDIDAYA DI LOMBOK, NUSA TENGGARA BARAT

\section{MORFOLOGI DAN HISTOLOGI HEPATOPANKREAS \\ (MIDGUT GLAND) \\ LOBSTER HIJAU PASIR (Panulirus homarus L.)}

KONTAMINASI JAMUR PADA RIMPANG KUNYIT

(Curcuma domestica Val.) DI PASAR KECAMATAN NANGA

TAYAP

HISTOPATOLOGI HATI TIKUS WISTAR PADA UJI

KETOKSIKAN AKUT PEWARNA MAKANAN DAUN JATI

(Tectona grandis L. $f$ )

PENINGKATAN KUALITAS PREPARAT AWETAN KUTU DENGAN VARIASI KONSENTRASI KOH DAN WAKTU CLEARING

PENGARUH KONSENTRASI PUPUK AMMONIUM SULFAT TERHADAP PERTUMBUHAN POPULASI SEL

Nannochloropsis sp.
Risa Umami 105-108

Faturrahman, Ernin Hidayati

$109-114$ dan Maria Ulfa

Handa Muliasari, Candra

115-118

Dwipayana Hamdin, Muhsinul Ihsan

Dewi Nur'aeni Setyowati, Nunik Cokrowati, M. Masyarul Rusdani

Muhsinul Ihsan, Istriyati, Handa Muliasari

Rahmawati, Siti Khotimah, 130-136 Mirawati

Candra Dwipayana Hamdin

Arya Iswara dan Fitri Nuroini.

Alis Mukhlis, Zaenal Abidin, Ibadur Rahman
125-129

$137-143$ $144-148$ 149-155

$119-124$

149-155

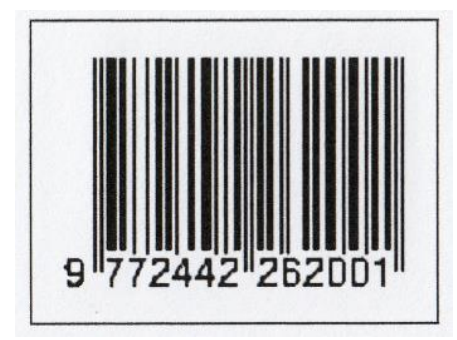




\title{
PENGARUH KONSENTRASI PUPUK AMMONIUM SULFAT TERHADAP PERTUMBUHAN POPULASI SEL Nannochloropsis $\mathbf{s p .}$
}

\author{
Alis Mukhlis ${ }^{1}$, Zaenal Abidin ${ }^{1}$, Ibadur Rahman ${ }^{1}$ \\ Program Studi Budidaya Perairan University of Mataram
}

\begin{abstract}
ABSTRAK
Tujuan dari penelitian ini adalah mengembangkan jenis pupuk yang murah untuk kultur Nannochloropsis sp. Dua jenis pupuk pertanian sebagai sumber unsur hara makro yaitu ammonium sulfat (pupuk ZA) dan TripleSuper Phosphate (pupuk TSP) dipilih sebagai pupuk alternatif. Dalam penelitian ini dilakukan kajian tentang pengaruh konsentrasi pupuk ZA yaitu $0 \mathrm{mg} / \mathrm{L}, 20 \mathrm{mg} / \mathrm{L}, 40 \mathrm{mg} / \mathrm{L}, 60 \mathrm{mg} / \mathrm{L}, 80 \mathrm{mg} / \mathrm{L}$ dan $100 \mathrm{mg} / \mathrm{L}$ terhadap kepadatan populasi sel maksimum, pertumbuhan relatif, waktu penggandaan diri, dan laju pertumbuhan spesifik populasi sel Nannochloropsis sp selama fase pertumbuhan eksponensial. Masing-masing konsentrasi pupuk ZA ditambahkan $10 \mathrm{mg} / \mathrm{L}$ pupuk TSP sebagai sumber unsur fosforus. Medium kaya nutrien yaitu KW21 digunakan sebagai kontrol. Penelitian menggunakan metoda eksperimen dengan kepadatan awal $\pm 2 \mathrm{x}$ $10^{6} \mathrm{sel} / \mathrm{mL}$ dan dipeliharan selama 72 jam masa percobaan. Pengamatan kepadatan dilakuan setiap 24 jam. Hasil penelitian menunjukkan bahwa kepadatan populasi sel maksimum Nannochloropsis sp. tertinggi dicapai pada konsentrasi pupuk ZA $40 \mathrm{mg} / \mathrm{L}$ dengan tingkat kepadatan populasi sel sebesar $12.950 \times 10^{3}$ sel/mL yang dicapai pada jam ke-72 setelah penebaran. Fase pertumbuhan eksponensial terjadi selama periode waktu 24 jam setelah penebaran dimana tingkat pertumbuhan relatif tertinggi dicapai pada konsentrasi $40 \mathrm{mg} / \mathrm{L}$ yaitu 277,47 \% dari kepadatan populasi sel saat penebaran. Waktu penggandaan diri Nannochloropsis sp. yang paling singkat selama fase pertumbuhan eksponensial diperoleh pada konsentrasi ZA $40 \mathrm{mg} / \mathrm{L}$ yaitu 12,52 jam atau 12 jam 31,2 menit dengan laju pertumbuhan spesifik sebesar 5,69\% per jam.
\end{abstract}

Kata kunci : Nannochloropsis, pertumbuhan, pupuk, ammonium.

\section{PENDAHULUAN}

Mikroalga telah lama digunakan sebagai pakan untuk berbagai spesies penting akuakultur termasuk kelompok bivalvia, stadia larva beberapa spesies krustasea, dan stadia perkembangan awal beberapa spesies ikan. Mikroalga juga dibutuhkan sebagai pakan untuk zooplankton (Brown dan Blackburn, 2013). Mikroalga mengandung asam lemak tak jenuh rantai panjang yang cukup tinggi, seperti asam dokosaheksanoat (DHA 22:6n3), asam eikosapentanoat (EPA 20:5n3), dan asam arakidonat (AA 20:4n6) yang sangat dibutuhkan untuk pertumbuhan dan kelangsungan hidup larva (Morais et al., 2005). Nannochloropsis sp. Merupakan salah satu spesies mikroalga yang paling umum digunakan dalam akuakultur (Pulz dan Gross, 2004) dan memiliki proporsi EPA (34\%) dan ARA (7\%) yang tinggi (Mourente et al., 1990; Volkman et al., 1990; 1993). Namun, demikian, produksi mikroalga sebagai pakan untuk organisme akuatik membutuhkan biaya yang tinggi (Jaime-Ceballos et al., 2006).

Salah satu faktor penyebab tingginya biaya produksi mikroalga adalah tingginya biaya media kultur terutama media yang mengandung senyawa murni yang dibuat khusus untuk kultur mikroalga. Beberapa penulis telah melaporkan penggunaan media tumbuh yang lebih murah seperti pupuk pertanian dalam kultur miroalga. Voltolina \& LopezElías (2002) in Campaña-Torres et al. (2012) melaporkan tentang kelayakan penggunaan pupuk pertanian dari sudut pandang teknis dan ekonomi untuk kultur diatom. Simental-Trinidad et al., (2002) juga melaporkan penggunaan pupuk pertanian dalam kultur awal diatom.

Tujuan dari penelitian ini adalah mengembangkan jenis pupuk yang murah untuk kultur Nannochloropsis sp. sebagai pakan alami dalam akuakultur. Dua jenis pupuk pertanian sebagai sumber unsur hara makro yaitu ammonium sulfat (pupuk ZA) dan Triple-Super Phosphate (pupuk TSP) digunakan sebagai pupuk alternatif. Pemilihan kedua jenis pupuk ini didasari pertimbangan bahwa keduanya sangat mudah ditemukan di pasaran sehingga memiliki potensi sebagai pengganti pupuk komersial yang umum digunakan dalam skala laboratorium seperti pupuk KW21 produk Jepang. Dalam penelitian ini dilakukan kajian tentang pengaruh konsentrasi 
pupuk ZA yang ditambahkan pupuk TSP terhadap pertumbuhan populasi sel Nannochloropsis sp. Konsentrasi pupuk TSP diatur pada tingkat yang sama di semua perlakuan.

\section{MATERI DAN METODE}

Penelitian ini dilaksanakan pada bulan Juni-November 2017 di Laboratorium Mini Mikroalga Laut, Jati Sesela, Gunung Sari, Lombok Barat. Penelitian menggunakan metode ekperimen terdiri atas 7 (tujuh) perlakuan yang diulang masing-masing sebanyak 3 kali ulangan. Perlakuan yang diuji yaitu konsentrasi pupuk ZA dalam media air, yaitu : $0 \mathrm{mg} / \mathrm{L}$ (perlakuan A), $20 \mathrm{mg} / \mathrm{L}$ (perlakuan B), $40 \mathrm{mg} / \mathrm{L}$ (perlakuan C), $60 \mathrm{mg} / \mathrm{L}$ (perlakuan D), $80 \mathrm{mg} / \mathrm{L}$ (perlakuan E), $100 \mathrm{mg} / \mathrm{L}$ (perlakuan F) dan perlakuan kontrol menggunakan medium KW21 dengan perbandingan $1 \mathrm{~mL}$ pupuk setiap 1 L media air. Pupuk TSP dengan konsentrasi $10 \mathrm{mg} / \mathrm{L}$ ditambahkan pada semua perlakuan kecuali pada perlakuan kontrol.

\section{Pupuk Pertanian dan Pupuk KW21}

Pupuk ammonium sulfat (ZA) dengan rumus kimia $\left(\mathrm{NH}_{4}\right)_{2} \mathrm{SO}_{4}$ \{mengandung $21 \%$ unsur nitrogen (N) dan 24\% unsur belerang (S) \} digunakan sebagai pupuk percobaan. Pupuk ini diperoleh dari pasar lokal penyedia pupuk pertanian. Pupuk pertanian lainnya yaitu pupuk Triple-Super Phosphate (TSP) dengan rumus Rumus kimia $\mathrm{Ca}\left(\mathrm{H}_{2} \mathrm{PO}_{4}\right)$ digunakan sebagai sumber unsur fosforus (P). Kadar $\mathrm{P}_{2} \mathrm{O}_{5}$ (fosfat) dalam pupuk ini sekitar 44-46\%. Pupuk lain yang digunakan yaitu pupuk komersil KW21 \{49 g/L nitrogen $(\mathrm{N}), 4 \mathrm{~g} / \mathrm{L}$ asam fosforik $(\mathrm{P})$, boron, mangan, besi, zink, kobal, EDTA, asam amino kompleks, campuran vitamin (B1, B12, biotin, dan lain-lain)\} juga disiapkan sebagai pembanding (kontrol)

Masing-masing jenis pupuk ZA dan TSP ditimbang sebanyak $10 \mathrm{~g}$ kemudian dilarutkan dalam masing-masing $100 \mathrm{~mL}$ air laut steril. Pupuk TSP terlebih dahulu digerus pada mortar hingga halus sebelum dilarutkan. Larutan pupuk disimpan pada suhu kamar hingga digunakan dalam penelitian.

\section{Perbanyakan Inokulan}

Bibit murni Nannochloropsis sp. diperoleh dari Balai Budidaya Laut Lombok dan dikultur lebih lanjut di laboratorium menggunakan medium KW21 pada media air bersalinitas $30 \mathrm{~g} / \mathrm{L}$. Sterilisasi media air dilakukan dengan metode pemanasan pada suhu di atas $100^{\circ} \mathrm{C}$ selama 5 menit. Kultur diatur pada intensitas cahaya 5.000-6.000 lux. Kultur awal dilakukan pada volume $2 \mathrm{~L}$ dengan lama pemeliharaan 4 (empat) hari kemudian diulang hingga mendapatkan jumlah populasi sel yang cukup untuk kebutuhan penelitian. Selama kultur, aerasi diberikan dengan intensitas sedang.

\section{Penebaran Bibit dan Pemeliharaan}

Kepadatan bibit pada awal penelitian diatur pada tingkat kepadatan populasi sel sebesar $\pm 2 \mathrm{x}$ $10^{6} \mathrm{sel} / \mathrm{mL}$. Pengamatan kepadatan populasi sel dilakukan dengan mengambil sebanyak $8 \mu \mathrm{L}$ sampel bibit Nannochloropsis sp. dan diletakkan pada hemositometer untuk diamati lebih lanjut di bawah mikroskop cahaya menggunakan pembesaran 100 dan 400x. Kepadatan sel dihitung dengan rumus : $P=N \times 10^{4} \mathrm{sel} / \mathrm{mL}$, dimana $P$ adalah kepadatan sel (sel/mL) dan $N$ adalah jumlah total sel pada bidang hemositometer seluas $1 \mathrm{~mm}^{2}$. Penentuan volume inokulan saat penebaran ditentukan dengan menggunakan rumus pengenceran. Pemeliharaan dilakukan dengan cara yang sama dengan saat perbanyakan bibit. Pengamatan kepadatan populasi sel Nannochloropsis sp. dilakukan setiap 24 jam hingga jam ke-72 (tiga hari setelah penebaran).

\section{Parameter Kualitas Air}

Parameter kualitas air yang diamati dalam penelitian ini meliputi suhu, salinitas, dan derajat keasaman air $(\mathrm{pH})$. Suhu diamati setiap dua hari yaitu pada pagi, siang, sore, dan malam hari. Salinitas dan $\mathrm{pH}$ diamati pada awal dan akhir penelitian.

\section{Parameter Uji}

Parameter yang diuji dalam penelitian ini yaitu kepadatan populasi sel maksimum yang dicapai selama 72 jam pemeliharaan, pertumbuhan relatif, waktu penggandaan diri dan laju pertumbuhan spesifik selama fase pertumbuhan eksponensial.

Kepadatan populasi sel Nannochloropsis sp. ditentukan melalui pengamatan secara mikroskopis pada haemositometer, sedangkan pertumbuhan relatif (relative growth rate) ditentukan menggunakan rumus :

$\mathrm{RGR}=\left(\left(C_{t}-C_{0}\right) / C_{0}\right) \times 100 \%$

RGR adalah relative growth rate (\%) sedangkan $C_{0}$ dan $C_{t}$ masing-masing adalah kepadatan populasi sel (sel $/ \mathrm{mL})$ pada awal dan akhir periode pengamatan.

Laju pertumbuhan spesifik (spesific growth rate) ditentukan dengan menggunakan rumus :

$\mathrm{SGR}=\left(\left(C_{t} / C_{0}\right)^{1 / t}-1\right) \times 100 \%$

SGR adalah spesific growth rate (\% per jam), $C_{0}$ dan $C_{t}$ masing-masing adalah kepadatan sel $(\mathrm{sel} / \mathrm{mL})$ pada awal dan akhir periode pengamatan, dan $t$ adalah lama periode pengamatan (jam). 
Waktu penggandaan diri (double time) ditentukan dengan menggunakan rumus :

$\mathrm{DT}=\log (2) \times \Delta t /\left(\log C_{t}-\log C_{0}\right)$

DT adalah double time (jam), $C_{0}$ dan $C_{t}$ masingmasing adalah kepadatan populasi sel $(\mathrm{sel} / \mathrm{mL})$ pada awal dan akhir periode pengamatan dan $\Delta t$ adalah lama waktu dalam satu periode pengamatan (jam).

\section{Analisis Data}

Data kepadatan populasi sel maksimum, pertumbuhan relatif, pertumbuhan spesifik, penggandaan diri dan laju pertumbuhan spesifik dianalisis secara statistik menggunakan analisis sidik ragam satu arah pada taraf $\alpha=5 \%$. Jika perlakuan menunjukkan pengaruh yang signifikan maka analisis dilanjutkan dengan uji beda nyata antar perlakuan menggunakan uji LSD (koefisien keragaman di atas 5\%) atau uji Tukey's HSD (koefisien keragaman di bawah 5\%) pada taraf yang sama.

\section{HASIL DAN PEMBAHASAN}

\section{Kepadatan populasi}

Hasil pengamatan menunjukkan bahwa pemberian pupuk ammonium sulfat (ZA) dengan konsentrasi berbeda-beda memberikan pengaruh tingkat kepadatan populasi sel maksimum yang beragam. Sebagian besar konsentrasi pupuk ZA yang diuji memberikan respon pertumbuhan yang kontinyu selama 72 jam masa pemeliharaan kecuali pada konsentrasi $100 \mathrm{mg} / \mathrm{L}$ yang memperlihatkan penurunan tingkat kepadatan populasi sel setelah 48 jam masa pemeliharaan. Dalam penelitian ini, kepadatan populasi sel maksimum dari urutan tertinggi secara berurutan dicapai oleh konsentrasi $40 \mathrm{mg} / \mathrm{L}\left(12.950 \times 10^{3} \mathrm{sel} / \mathrm{mL}\right), 20 \mathrm{mg} / \mathrm{L}(11.583 \times$ $\left.10^{3} \mathrm{sel} / \mathrm{mL}\right), 0 \mathrm{mg} / \mathrm{L}\left(9.733 \times 10^{3} \mathrm{sel} / \mathrm{mL}\right), 60 \mathrm{mg} / \mathrm{L}$ $\left(8.992 \times 10^{3} \mathrm{sel} / \mathrm{mL}\right), 80 \mathrm{mg} / \mathrm{L}\left(7.858 \times 10^{3}\right.$ $\mathrm{sel} / \mathrm{mL})$, kontrol $\left(7.658 \times 10^{3} \mathrm{sel} / \mathrm{mL}\right)$ dan $100 \mathrm{mg} / \mathrm{L}$ $\left(6.397 \times 10^{3} \mathrm{sel} / \mathrm{mL}\right)($ Tabel 1).

Hasil analis keragaman (Tabel 4) menunjukkan bahwa kepadatan populasi sel maksimum Nannochloropsis sp. tertinggi yang dicapai pada konsentrasi ZA $40 \mathrm{mg} / \mathrm{L}$ terlihat tidak berbeda nyata dengan respon yang ditunjukkan oleh konsentrasi $20 \mathrm{mg} / \mathrm{L}$ dan $0 \mathrm{mg} / \mathrm{L}$ (TSP sebagai pupuk tunggal). Meskipun pada konsentrasi $0 \mathrm{mg} / \mathrm{L}$ tidak dilakukan penambahan pupuk ZA sebagai sumber nitrogen namun pertumbuhan populasi sel Nannochloropsis sp. tetap berlangsung dan diduga karena mikroalga memanfaatkan unsur nitrogen yang tersedia secara alami dalam media air laut sebagai media kultur meskipun tersedia dalam jumlah yang sangat terbatas. Hal ini dijelaskan oleh $\mathrm{Hu}$ (2004) bahwa ketika kandungan nitrogen turun di bawah nilai ambang batas, fotosintesis masih dapat berlanjut, meskipun berada pada tingkat yang lebih rendah.

Nitrogen merupakan nutrisi terpenting bagi mikroalga setelah karbon dan memiliki peranan pada pertumbuhan mikroalga. Hampir semua alga yang mengandung klorofita tumbuh dengan baik dalam kondisi ketersediaan nitrogen yang cukup (Syrett, 1981 in Burford dan Pearson, 1998). Kandungan nitrogen dari suatu biomassa dapat berkisar dari $1 \%$ sampai lebih dari $10 \%$ dan tidak hanya bervariasi antara kelompok tetapi juga dalam spesies tertentu, tergantung pada suplai dan ketersediaannya dalam media (Becker, 1994). Sebagian besar nitrogen dipasok dalam bentuk nitrat $\left(\mathrm{NO}_{3}{ }^{-}\right)$, namun ammonium $\left(\mathrm{NH}_{4}{ }^{+}\right)$dan urea juga sering digunakan, dengan tingkat pertumbuhan yang serupa (Kaplan et al., 1986). Peningkatan ketersediaan pupuk ZA dari $0 \mathrm{mg} / \mathrm{L}$ hingga 40 $\mathrm{mg} / \mathrm{L}$ telah terbukti meningkatkan pertumbuhan namun demikian konsentrasi yang terus ditingkatkan melebihi $40 \mathrm{mg} / \mathrm{L}$ akan memberikan respon sebaliknya.

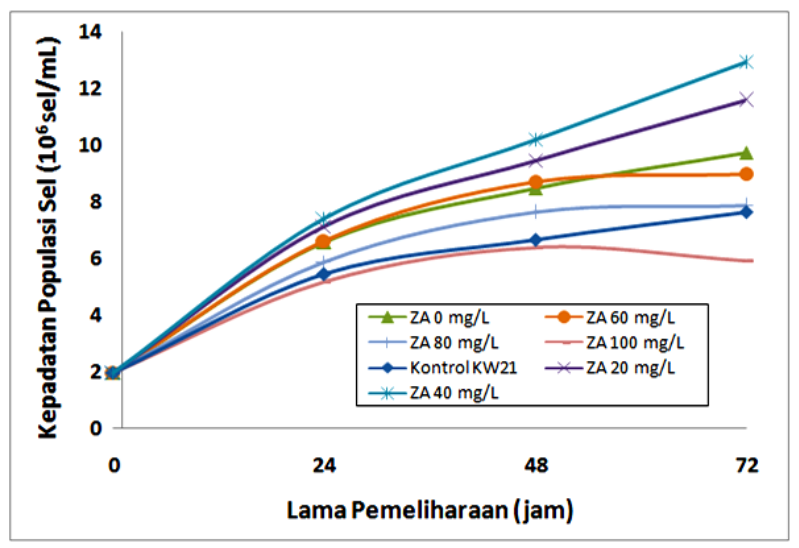

Gambar 1. Grafik pola pertumbuhan populasi sel Nannochloropsis sp. yang dikultur dengan pupuk TSP $10 \mathrm{mg} / \mathrm{L}$ dan dicampur pupuk ZA dengan konsentrasi $0 \mathrm{mg} / \mathrm{L}, 20 \mathrm{mg} / \mathrm{L}, 40 \mathrm{mg} / \mathrm{L}, 60 \mathrm{mg} / \mathrm{L}, 80$ $\mathrm{mg} / \mathrm{L}$ dan $100 \mathrm{mg} / \mathrm{L}$. Kultur dengan medium KW21 digunakan sebagai kontrol.

Penambahan pupuk TSP $10 \mathrm{mg} / \mathrm{L}$ sebagai sumber fosforus di semua perlakuan (kecuali kontrol) baik yang dicampur maupun yang tidak dicampur dengan pupuk ZA telah memberikan respon tingkat pertumbuhan maksimum yang lebih tinggi dibandingkan dengan medium KW21 selama 72 jam masa pemeliharaan. Fosforus adalah salah satu makronutrien utama yang memiliki peranan 
penting dalam proses metabolisme sel sebagai pembentuk berbagai komponen struktural dan fungsional yang diperlukan sel untuk pertumbuhan dan perkembangan mikroalga secara normal dimana kandungannya di dalam sel sekitar $1 \%$ dari berat kering (Goldman, 1980). Penelitian ini menunjukkan pentingnya ketersediaan fosforus untuk pertumbuhan mikroalga.

\section{Pertumbuhan Relatif}

Pola pertumbuhan populasi sel Nannochloropsis sp. pada konsentrasi ZA $0 \mathrm{mg} / \mathrm{L}$, $20 \mathrm{mg} / \mathrm{L}, 40 \mathrm{mg} / \mathrm{L}$ dan perlakuan kontrol yang terjadi hingga jam ke-72 menunjukkan peningkatan pertumbuhan yang relatif stabil (Gambar 1) terlihat dari nilai pertumbuhan relatif pada periode terakhir yang cenderung lebih tinggi $(14,75 \%-26,83 \%)$ dibandingkan dengan konsentrasi $60 \mathrm{mg} / \mathrm{L}, 80$ $\mathrm{mg} / \mathrm{L}$ dan $100 \mathrm{mg} / \mathrm{L}$ (minus 12,26\% s.d 1,63\%) (Tabel 2).

\section{Fase Pertumbuhan Eksponensial}

Berdasarkan data pertumbuhan relatif pada Tabel 2, nilai rata-rata pertumbuhan relatif pada periode pertama (jam ke-0 s.d jam ke-24) menunjukkan nilai di atas $100 \%$ artinya bahwa peningkatan kepadatan populasi sel Nannochloropsis sp. pada akhir periode ini mengalami peningkatan lebih dari satu kali lipat dari awal penebaran dan hal ini memenuhi kriteria sebagai fase pertumbuhan eksponensial.

Data yang berbeda ditunjukkan oleh pertumbuhan relatif pada periode ke-2 (jam ke-24 s.d jam ke-48) dan periode ke-3 (jam ke-48 s.d jam ke-72) dimana nilai rata-rata pertumbuhan relatif yang diperoleh berada di bawah nilai $100 \%$ dan hal ini terlihat di semua perlakuan. Data ini menunjukkan bahwa penggunaan pupuk KW21 maupun campuran pupuk TSP dengan pupuk ZA sama-sama memberikan respon pertumbuhan eksponensial yang sama pada Nannochloropsis sp. dimana rentang waktu pertumbuhan eksponensialnya hanya berlangsung hingga jam ke24 setelah penebaran.

Tabel 1. Kepadatan populasi sel Nannochloropsis sp. selama 72 jam dengan pemberian pupuk TSP konsentrasi $10 \mathrm{mg} / \mathrm{L}$ yang dicampur dengan pupuk ZA (konsentrasi $0 \mathrm{mg} / \mathrm{L}, 20 \mathrm{mg} / \mathrm{L}, 40 \mathrm{mg} / \mathrm{L}, 60$ $\mathrm{mg} / \mathrm{L}, 80 \mathrm{mg} / \mathrm{L}$ dan $100 \mathrm{mg} / \mathrm{L}$ ) dan medium KW21 sebagai perlakuan kontrol.

\begin{tabular}{rrrrrrrr}
\hline & \multicolumn{9}{c}{ Konsentrasi Pupuk ZA (mg/L) } & \multicolumn{2}{c}{ Kontrol } \\
\cline { 2 - 6 } Jam ke- & $\mathbf{0}$ & $\mathbf{2 0}$ & $\mathbf{4 0}$ & $\mathbf{6 0}$ & $\mathbf{8 0}$ & $\mathbf{1 0 0}$ & (KW21) \\
\hline 0 & 1.967 & 1.967 & 1.967 & 1.967 & 1.967 & 1.967 & 1.967 \\
24 & 6.583 & 7.133 & 7.425 & 6.633 & 5.867 & 5.185 & 5.442 \\
48 & 8.488 & 9.464 & 10.218 & 8.705 & 7.623 & $\mathbf{6 . 3 9 7}$ & 6.674 \\
72 & $\mathbf{9 . 7 3 3}$ & $\mathbf{1 1 . 5 8 3}$ & $\mathbf{1 2 . 9 5 0}$ & $\mathbf{8 . 9 9 2}$ & $\mathbf{7 . 8 5 8}$ & 5.913 & $\mathbf{7 . 6 5 8}$ \\
\hline
\end{tabular}

Catatan : Angka-angka yang dicetak tebal menunjukkan kepadatan populasi maksimum yang diperoleh selama percobaan.

Tabel 2. Pertumbuhan relatif Nannochloropsis sp. pada tiga periode pengamatan dengan pemberian pupuk TSP konsentrasi $10 \mathrm{mg} / \mathrm{L}$ yang dicampur dengan pupuk ZA (konsentrasi $0 \mathrm{mg} / \mathrm{L}, 20 \mathrm{mg} / \mathrm{L}, 40$ $\mathrm{mg} / \mathrm{L}, 60 \mathrm{mg} / \mathrm{L}, 80 \mathrm{mg} / \mathrm{L}$ dan $100 \mathrm{mg} / \mathrm{L}$ ) dan medium KW21 sebagai kontrol.

\begin{tabular}{cccc}
\hline \multirow{2}{*}{ Konsentrasi Pupuk ZA } & \multicolumn{2}{c}{ Rata-rata Pertumbuhan Relatif Harian \pm S.D (\%) Setelah Penebaran (hari) } \\
\cline { 2 - 4 } & Jam ke-0 s.d ke-24 & Jam ke-24 s.d ke-48 & Jam ke-48 s.d ke-72 \\
\hline $0 \mathrm{mg} / \mathrm{L}$ & $234.78 \pm 1.39$ & $29.39 \pm 10.94$ & $15.14 \pm 17.80$ \\
$20 \mathrm{mg} / \mathrm{L}$ & $262.67 \pm 1.50$ & $33.01 \pm 18.13$ & $21.80 \pm 8.28$ \\
$40 \mathrm{mg} / \mathrm{L}$ & $277.47 \pm 4.27$ & $37.65 \pm 11.10$ & $26.83 \pm 8.67$ \\
$60 \mathrm{mg} / \mathrm{L}$ & $237.26 \pm 1.18$ & $32.48 \pm 30.95$ & $1.44 \pm 16.77$ \\
$80 \mathrm{mg} / \mathrm{L}$ & $197.94 \pm 14.75$ & $33.36 \pm 47.05$ & $1.63 \pm 12.11$ \\
$100 \mathrm{mg} / \mathrm{L}$ & $163.62 \pm 2.73$ & $23.44 \pm 30.46$ & $-12.26 \pm 27.18$ \\
Kontrol (KW21) & $176.58 \pm 4.28$ & $23.19 \pm 8.51$ & $14.75 \pm 3.11$ \\
\hline
\end{tabular}

$S . D=$ Standar Deviasi 
Tabel 3. Waktu penggandaan diri dan laju pertumbuhan spesifik (SGR) Nannochloropsis sp. selama fase eksponensial dengan pemberian pupuk TSP konsentrasi $10 \mathrm{mg} / \mathrm{L}$ yang dicampur dengan pupuk ZA (konsentrasi $0 \mathrm{mg} / \mathrm{L}, 20 \mathrm{mg} / \mathrm{L}, 40 \mathrm{mg} / \mathrm{L}, 60 \mathrm{mg} / \mathrm{L}, 80 \mathrm{mg} / \mathrm{L}$ dan $100 \mathrm{mg} / \mathrm{L}$ ) dan medium KW21 sebagai kontrol.

\begin{tabular}{ccc}
\hline Konsentrasi ZA & $\begin{array}{c}\text { Waktu Penggandaan } \\
\text { (jam) }\end{array}$ & $\begin{array}{c}\text { SGR Saat Pertumbuhan Eksponensial } \\
\text { (\% per jam) }\end{array}$ \\
\hline $40 \mathrm{mg} / \mathrm{L}$ & 12,52 & 5,69 \\
$20 \mathrm{mg} / \mathrm{L}$ & 12,91 & 5,51 \\
$60 \mathrm{mg} / \mathrm{L}$ & 13,68 & 5,20 \\
$0 \mathrm{mg} / \mathrm{L}$ & 13,77 & 5,16 \\
$80 \mathrm{mg} / \mathrm{L}$ & 15,27 & 4,65 \\
Kontrol (KW21) & 16,36 & 4,33 \\
$100 \mathrm{mg} / \mathrm{L}$ & 17,16 & 4,12 \\
\hline
\end{tabular}

Waktu Penggandaan Diri dan Laju Pertumbuhan Spesifik pada Fase Pertumbuhan Eksponensial

Hasil analisis waktu penggandaan diri (double time) dan laju pertumbuhan spesifik yang terjadi selama fase pertumbuhan eksponensial (Tabel 3) menunjukkan bahwa waktu penggandaan diri Nannochloropsis sp. tersingkat ditunjukkan oleh konsentrasi ZA $40 \mathrm{mg} / \mathrm{L}$ dengan nilai rata-rata sebesar 12,52 jam atau 12 jam 31,2 menit. Pada perlakuan ini, pertumbuhan populasi sel Nannochloropsis sp. mengalami peningkatan dengan laju pertumbuhan sebesar 5,69\% per jam. Waktu penggandaan diri paling panjang ditunjukkan oleh konsentrasi pupuk ZA $100 \mathrm{mg} / \mathrm{L}$ dengan nilai rata-rata 17,16 jam atau 17 jam 9,6 menit dengan laju pertumbuhan rata-rata sebesar $4,12 \%$ per jam.

\section{Kadar Klorofil Sel}

Meskipun pemberian pupuk KW21 menunjukkan nilai rata-rata tingkat kepadatan populasi sel maksimum, pertumbuhan dan waktu penggandaan diri yang lebih rendah dari perlakuan konsentrasi pupuk ZA $0 \mathrm{mg} / \mathrm{L}, 20 \mathrm{mg} / \mathrm{L}, 40 \mathrm{mg} / \mathrm{L}$, $60 \mathrm{mg} / \mathrm{L}$ dan $80 \mathrm{mg} / \mathrm{L}$, namun tampilan warna populasi sel Nannochloropsis sp. pada perlakuan ini menunjukkan warna hijau yang lebih tua sebagai indikator terjadinya peningkatan kadar klorofil dalam sel dibandingkan dengan perlakuan lainnya (Gambar 2). Hasil pengamatan secara mikroskopis (Gambar 3) juga menunjukkan bahwa sel Nannochloropsis sp. yang diberi pupuk KW21 menunjukkan warna hijau yang lebih tua dibandingkan tanpa pemberian pupuk ZA (konsentrasi $0 \mathrm{mg} / \mathrm{L}$ ). Perubahan warna pada sel yang disebabkan oleh penurunan kadar klorofil merupakan ciri khas dari kondisi keterbatasan nitrogen (Becker, 1994; Hu, 2004).

Menurunnya kadar klorofil memberikan pengaruh positif jika dilihat dari peningkatan akumulasi lipid, karbohidrat dan karotenoid. $\mathrm{Hu}$ (2004) menjelaskan bahwa ketika mikroalga berada dalam kondisi kekurangan nitrogen maka aliran karbon yang terfiksasi dalam proses fotosintesis akan dialihkan dari jalur sintesis protein menuju jalur sintesis lipid atau karbohidrat menyebabkan terjadinya peningkatan senyawa karbon organik seperti polisakarida dan minyak tertentu (PUFA) di dalam sel. Lebih lanjut dijelaskan oleh Thompson (1996) bahwa dalam kondisi ini jumlah triasilgliserol sebagai komponen lipid juga mengalami peningkatan.

Akumulasi karotenoid sekunder yang disertai dengan penurunan kadar klorofil sel merupakan ciri utama lainnya di berbagai jenis alga klorofita saat dikultur dengan kondisi keterbatasan nitrogen (Hu, 2004). Ben-Amotz et al. (1982) in $\mathrm{Hu}$ (2004) melaporkan bahwa produksi $\beta$-karoten pada sel Dunaliella mengalami peningkatan ketika jumlah nitrogen sangat terbatas. Selain itu, Borowitzka et al. (1991) melaporkan bahwa konsentrasi nitrogen yang rendah merupakan faktor utama meningkatnya sintesis dan akumulasi astaxanthin dan asilester pada Haematococcus pluvialis. Hal ini menarik untuk dikaji lebih lanjut terkait dengan pemanfaatan Nannochloropsis sp. sebagai pengkaya nutrisi Brachionus spp. yang merupakan pakan langsung bagi larva ikan laut.

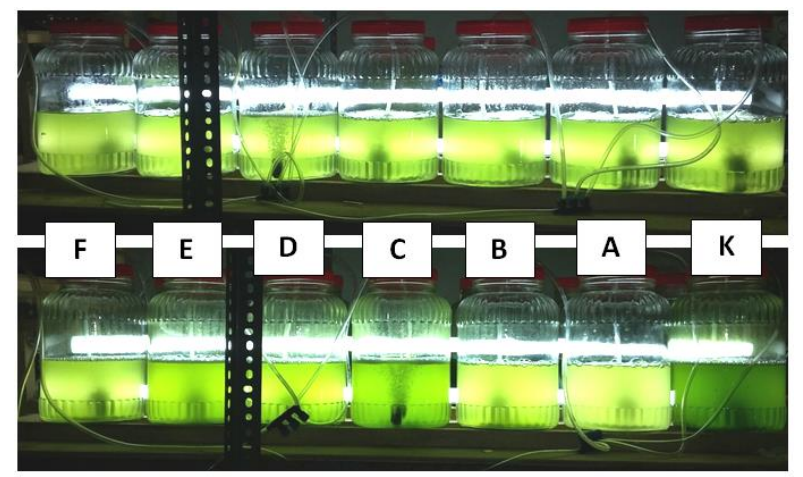

Gambar 2. Kondisi kultur Nannochloropsis sp. skala laboratorium. Keterangan : $\mathrm{A}=0$ $\mathrm{mg} / \mathrm{L} \mathrm{ZA} ; \mathrm{B}=20 \mathrm{mg} / \mathrm{L} \mathrm{ZA}, 40 \mathrm{mg} / \mathrm{L}$ $\mathrm{ZA}, 60 \mathrm{mg} / \mathrm{L} \mathrm{ZA}, 80 \mathrm{mg} / \mathrm{L} \mathrm{ZA}$, dan 100 
mg/L ZA. K = Pupuk KW21 yang digunakan sebagai kontrol. Gambar atas: kondisi kultur awal (jam ke-0); Gambar bawah : kondisi kultur akhir (jam ke-72)

Hasil analisis parameter kualitas air menunjukkan bahwa salinitas media air selama percobaan relatif pada tingkat salinitas 30 promil. Tingkat keasaman air sedikit menurun dari kisaran
7,1-7,2 pada awal percobaan menurun menjadi 6,76,9 pada akhir percobaan. Suhu pada media air berada pada kisaran $30-32{ }^{\circ} \mathrm{C}$. Suhu tertinggi dicapai pada siang hingga menjelang sore hari, sedangkan terendah terjadi pada malam hingga pagi hari. Kisaran parameter kualitas air yang diukur dalam penelitian ini relatif homogen di semua perlakuan dan masih dalam batas yang layak untuk pertumbuhan Nannochloropsis sp.
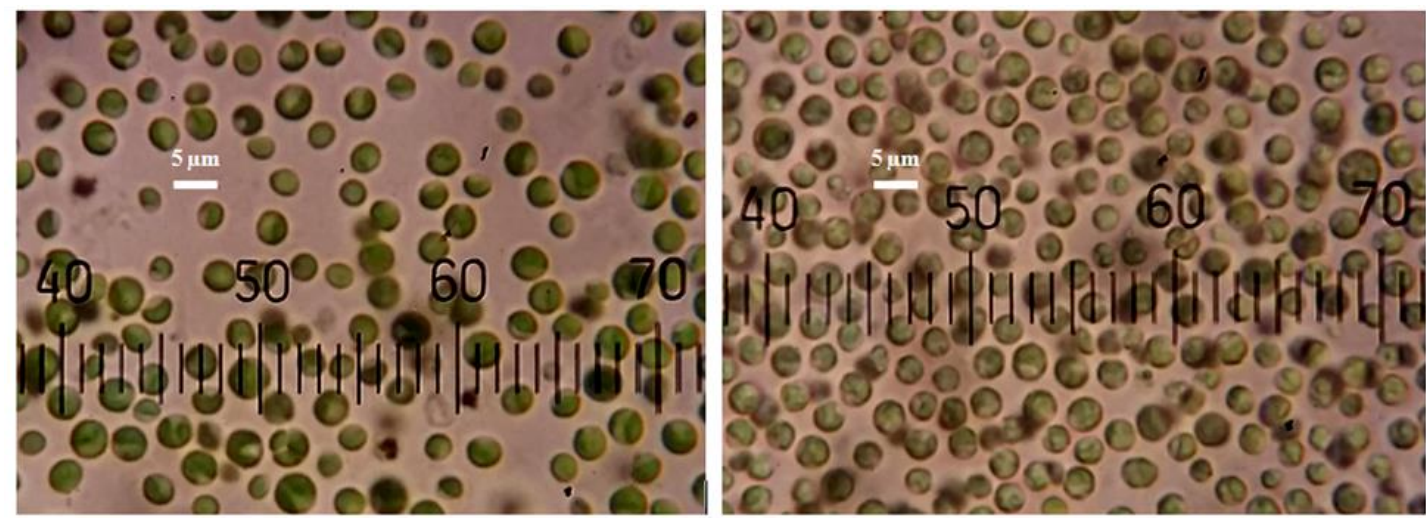

Gambar 3. Tampilan sel Nannochloropsis sp. yang diamati di bawah mikroskop dengan pembesaran 400x. Gambar kiri : kultur menggunakan medium KW21, memperlihatkan sel dengan warna hijau tua; Gambar kanan : kultur menggunakan pupuk $10 \mathrm{mg} / \mathrm{L}$ TSP tanpa penambahan ZA, memperlihatkan sel dengan warna hijau pucat.

Tabel 4. Hasil uji beda nyata antar perlakuan

\begin{tabular}{lcccr}
\hline $\begin{array}{l}\text { Konsentrasi Pupuk } \\
\text { ZA }\end{array}$ & $\begin{array}{c}\text { Pertumbuhan } \\
\text { Relatif (\%) Saat } \\
\text { Pertumbuhan } \\
\text { Ekponensial }\end{array}$ & $\begin{array}{c}\text { Waktu Penggandaan } \\
\text { Diri Saat Pertumbuhan } \\
\text { Eksponensial (jam) }\end{array}$ & $\begin{array}{c}\text { LPS saat Pertumbuhan } \\
\text { Eksponensial } \\
\text { (\% per jam) }\end{array}$ & $\begin{array}{c}\text { Kepadatan } \\
\text { Maksimum } \\
(\mathbf{1 . 0 0 0} \text { sel/mL) }\end{array}$ \\
\hline $0 \mathrm{mg} / \mathrm{L}$ & $234.78 \mathrm{c}$ & $13.77 \mathrm{~d}$ & $5.16 \mathrm{c}$ & $9.733 \mathrm{abc}$ \\
$20 \mathrm{mg} / \mathrm{L}$ & $262.67 \mathrm{~d}$ & $12.91 \mathrm{ef}$ & $5.51 \mathrm{~d}$ & $11.583 \mathrm{bc}$ \\
$40 \mathrm{mg} / \mathrm{L}$ & $277.47 \mathrm{~d}$ & $12.52 \mathrm{f}$ & $5.69 \mathrm{~d}$ & $12.950 \mathrm{c}$ \\
$60 \mathrm{mg} / \mathrm{L}$ & $237.26 \mathrm{c}$ & $13.68 \mathrm{de}$ & $5.20 \mathrm{c}$ & $8.992 \mathrm{ab}$ \\
$80 \mathrm{mg} / \mathrm{L}$ & $197.94 \mathrm{~b}$ & $15.27 \mathrm{c}$ & $4.65 \mathrm{~b}$ & $7.858 \mathrm{a}$ \\
$100 \mathrm{mg} / \mathrm{L}$ & $163.62 \mathrm{a}$ & $17.16 \mathrm{a}$ & $4.12 \mathrm{a}$ & $6.397 \mathrm{a}$ \\
Kontrol (KW21) & $176.58 \mathrm{a}$ & $16.36 \mathrm{~b}$ & $4.33 \mathrm{a}$ & $7.658 \mathrm{a}$ \\
\hline
\end{tabular}

Catatan : angka-angka yang diikuti oleh huruf yang sama menunjukkan tidak berbeda nyata $(\alpha=5 \%)$

\section{KESIMPULAN}

Kesimpulan yang dapat diambil dari penelitian ini yaitu :

1. Kepadatan populasi sel maksimum Nannochloropsis sp. tertinggi dicapai pada campuran $10 \mathrm{mg} / \mathrm{L}$ pupuk TSP dan $40 \mathrm{mg} / \mathrm{L}$ pupuk ZA dengan tingkat kepadatan sel sebesar $12.950 \times 10^{3} \mathrm{sel} / \mathrm{mL}$ yang dicapai pada jam ke72 setelah penebaran.

2. Fase pertumbuhan eksponensial populasi sel Nannochloropsis sp. terjadi dalam selang waktu 24 jam setelah penebaran;
3. Pertumbuhan relatif populasi sel Nannochloropsis sp. tertinggi selama fase eksponensial terjadi pada campuran $10 \mathrm{mg} / \mathrm{L}$ pupuk TSP dan $40 \mathrm{mg} / \mathrm{L}$ pupuk ZA dengan nilai sebesar $277,47 \%$ dari kepadatan populasi sel saat penebaran;

4. Campuran $10 \mathrm{mg} / \mathrm{L}$ pupuk TSP dan $40 \mathrm{mg} / \mathrm{L}$ pupuk ZA menghasilkan waktu penggandaan diri Nannochloropsis sp. paling singkat pada fase eksponensial dengan nilai sebesar 12,52 jam atau 12 jam 31,2 menit dengan laju pertumbuhan populasi sel sebesar 5,69\% per jam. 


\section{DAFTAR PUSTAKA}

Becker, E.W. 1994. Microalgae: Biotechnology and microbiology. Cambridge University Press. 293 hal.

Brown, M.R. and Blackburn, S.I. 2013. Live microalgae as feeds in aquaculture hatcheries. Advances in aquaculture hatchery technology. (C) Woodhead Publishing Limited : 118-156.

Borowitzka, M.A., J.M. Huisman dan A. Osborn. 1991. Cultures of the astaxanthinproducing green alga Haematococcus pluvialis. I. Effect of nutrient on growth and cell type. J. Appl. Phycol. Vol. 3 : 295-304.

Burford, M.A. dan D.C. Pearson. 1998. Effect of different nitrogen sources on phytoplankton composition in aquaculture ponds. Aquatic Microbial Ecology. 15 : 277-282.

Campaña-Torres, A., L.R. Martínez-Córdova, M. Martínez-Porchas, J.A López-Elías. M.A. Porchas-Cornejo. 2012. Productive response of Nannochloropsis oculata, cultured in different media and their efficiency as food for the rotifer Brachionus rotundiformis. ФYTON. $81: 44-50$

Goldman, J.C. 1980. Physiological aspects in algal mass cultures. Di dalam : Algal Biomass (Shelef, G. dan C.J. Soeder, editor). Elsevier/North-Holland Biomedical Press. 343 hal

Hu, Q. 2004. Environmental Effects on Cell Composition. Di dalam : Handbook of Microalgal Culture: Biotechnology and Applied Phycology (Richmond, A., editor). Blackwell Publishing Ltd. : 83-93.

Jaime-Ceballos, B. J., Hernández-Llamas, A., García-Galano, T., Villarreal, H. 2006. Substitution of Chaetoceros muelleri by Spirulina platensis meal in diets for
Litopenaeus schmitti larvae. Aquaculture. 260, $215-220$.

Kaplan, D., A.E. Richmond, Z. Dubinsky dan A. Aaronson. 1986. Algal nutrition. Di dalam : Handbook of Microalgal Mass Culture (Richmond, A., editor). CRC Press : 147-98.

Morais, S., Koven, W., Rønnestad, I., Dinis, M. T., Conceição, L. E. C. 2005. Dietary protein: lipid ratio and lipid nature affects fatty acid absorption and metabolism in a teleost larva. Brit. J. Nutr. 93, $813-820$.

Mourente G, Lubian L M dan Odriozola J M. 1990. Total fatty acid composition as a taxonomic index of some marine microalgae used as food in marine aquaculture. Hydrobiologia, 203, 147-154.

Pulz, O., Gross, W. 2004. Valuable products from biotechnology of microalgae. Appl. Microbiol. Biotechnol. 65, 635 - 648 .

Simental-Trinidad, J.A., M.P. Sánchez-Saavedra dan J.G. Correa-Reyes. 2002. Biochemical composition of benthic manine diatoms using as culture medium a common agricultural fertilizer. Journal of Shellfish Research. 20:611-617.

Thompson, Jr. G.A. 1996. Lipids and membrane function in green algae. Biochem. Biophys. Acta. 1302 : 17-45.

Volkman J K, Brown M R, Dunstan G A And Jeffrey S W. 1993. The biochemical composition of marine microalgae from the class Eustigmatophyceae. Journal of Phycology, 29, 69-78.

\section{UCAPAN TERIMA KASIH}

Ucapan terima kasih disampaikan kepada Kementerian Riset dan Pendidikan Tinggi atas Dana Penelitian yang diberikan melalui DANA DIPA BLU UNIVERSITAS MATARAM Tahun Anggaran 2017 dengan Nomor Kontrak : 756U/UN18/LPPM/2017. 